\title{
O IGNOTO VIANDANTE E O ITINERÁRIO RUMO AO NADA
}

\author{
Carolina Donega BERNARDES ${ }^{1}$
}

\begin{abstract}
RESUMO: A Odisseia (1938) de Kazantzakis (1883-1957) está estreitamente relacionada com Ascese (1927), sua obra anterior, seja na trajetória do herói Odisseu, seja na fundamentação filosófica que corporifica o personagem. Procuramos, neste artigo, perceber como se constitui a figura do herói por meio de sua trajetória ascética, que se dá a partir do canto XIV, percorrendo igualmente as etapas de superação que estruturam Ascese e comparecem claramente na Odisseia. Assim, preocupamo-nos em realizar uma análise crítica das etapas vividas pelo personagem para compreender como Odisseu abandona a fama e seu nome e se torna o desconhecido viajante, em direção ao nada.
\end{abstract}

PALAVRAS-CHAVE: Odisseia; Ascese; superação; anonimato; filosofia.

ABSTRACT: The Odyssey, written by Kazantzakis, is deeply related to Ascese (The Saviors of God: Spiritual Exercises), his previous work, as we can see by the Odysseus' way or by the philosophical foundation that forms the main character of the book. In this article, we try to perceive how the heroes figure of Odysseus is shaped by his ascetic way, that begins in the XIV book, and to understand his travel between overcoming stages that are similar to Ascese's ascetic course. Thus, to critically analyze the different phases lived by the character is our concern. In such a manner, we can comprehend how Odysseus abandons the fame and his name to become the unknown traveler that walks bounded to the nothingness.

KEYWORDS: Odyssey; Spritual Exercises; overcoming; anonymity; philosophy.

\section{A Preparação}

A figura de Odisseu constitui, desde o início de sua existência mítico-literária, um modelo, uma forma "multiforme" (polytropos) de vida humana cheia de potencialidades. As múltiplas características do herói lendário provêm das diversas tradições clássicas que procuraram traçar seus passos, desde o nascimento até seu retorno à pátria, e de diversas interpretações de sua simbologia por filósofos e escritores. O legado de Ulisses que parece ter suscitado maior abertura para especulações e tentativas de compreensão do mito se instala na própria Odisseia de 
Homero, com a previsão do adivinho Tirésias, quando o herói faz sua descensão ao Hades. Como é comum nas previsões de adivinhos e oráculos, a mensagem de Tirésias prolonga-se ao futuro por sua ambigüidade, marcada na expressão grega thanatos ex halos, que pode significar que o herói teria uma morte "vinda do mar" ou "distante do mar”. Por essa previsão, Odisseu torna-se uma figura de longa duração, aberta às diversas interpretações, que intentam completar o anúncio de Tirésias. Assim, além de revelar a morte do herói pela expressão ambígua, o adivinho abre mais uma possibilidade para o futuro: sua viagem não terminaria com a chegada a Ítaca, como ocorre em Homero, mas se prolongaria para além do nóstos. Desse modo, Odisseu torna-se o viajante por excelência, ininterruptamente.

Inúmeras vezes recuperado pela tradição literária, o tema da viagem de Ulisses foi desenvolvido por autores como Dante Alighieri, Shakespeare, Giovanni Pascoli, Gabriele d'Annunzio, Alfred Tennyson, James Joyce, Haroldo de Campos, Nikos Kazantzákis, entre outros, seja para confirmar o ideal do herói nostálgico, que reencontra a terra natal, seja para reafirmar o ímpeto do herói, representando-o como eterno navegador de mares. Apesar de muitos autores se inspirarem no retorno de Ulisses como meta da navegação, é forte a tradição que escolhe representar o herói como insatisfeito com a chegada ao lar almejado e desejoso de continuar a viagem.

Extensa e variada é a discussão acerca da "última viagem de Odisseu", explorada por escritores de todos os tempos, no entanto interessa-nos por ora incursionar na obra de Kazantzákis, autor que dedicou 33.333 versos à marcha incessante de Odisseu na poesia épicaOdisseia (1938), uma continuação da epopeia de Homero.

O Odisseu kazantzakiano, semelhante à interpretação dada por Tennyson2, segue adiante em sua navegação, após a insatisfação sentida em relação à pátria e à família. Homem de múltiplos conhecimentos, experiente e sábio, o Odisseu de Kazantzákis não se contenta com os valores tradicionais e estabelecidos, deseja a fruição completa da vida. Tal sede de conhecimento e de experiências não é, porém, hedonística ou de mero aproveitamento da vida em sua plenitude, mas liga-se à ideia de prolongar as ações dos antepassados, de modo que não sejam esquecidos e não se 
dissolvam no mundo dos mortos e sim que sirvam de adubo, de impulso para que o descendente siga mais longe, superando-se e promovendo a fundação do super-homem.

A superação, representada aqui pelo eterno viajar, associa-se ao pensamento de Nietzsche, filósofo que, por meio de Zaratustra, incentiva a força nos homens, sem qualquer intervenção divina. Em comunhão com diversas ideias de Nietzsche, e ainda com o conceito de élan vital de Bergson e da religião budista, Kazantzákis compõe seu próprio itinerário de superação e a ele nomeia ascese. Antes mesmo de encontrar em Ulisses seu protótipo de herói e de oferecer-lhe uma nova jornada a partir do retorno à Ítaca, o autor já elaborara em Ascese Ossalvadores de Deus (1927) as etapas de elevação para o alcance da liberdade plena.

Para Kazantzákis, a ascese não é a simples elevação ao sagrado por meio de mortificações ao corpo praticadas por ascetas e religiosos, mas é um percurso de superação de valores, dogmas e conceitos, formadores do pensamento e atitudes do homem, que o impedem de realizar avaliações próprias da realidade e ceifam seu poder criador. Assim, o autor não adota um único caminho para compor sua visão de mundo, mas aponta em várias direções como possibilidades para as escolhas criadoras do homem. A ascese kazantzakiana indica que o entendimento apurado e mais próximo da completude de um determinado conceito ou valor só poderá ser alcançado com o apoio de diversas formas de pensamento, com a abertura das perspectivas, com a variação dos prismas.

Coadunado com o pensamento de Nietzsche, Kazantzákis expressa sua desconfiança pelos valores que inibem o potencial criativo do homem, considerados como "niilistas". Para combater esse niilismo negativo e restituir ao homem o direito à criação, Nietzsche elabora uma estratégia igualmente "niilista", mas ativa: inverter e superar a oposição de valores criada pelo platonismo e pelo cristianismo, afirmar que o mundo sensível é o mundo verdadeiro e o supra-sensível o mundo aparente, rebelar-se contra a dicotomia de dois mundos e a oposição metafísica entre a verdade e a aparência. O mais importante dessa estratégia de transvaloração não é apenas a quebra dos valores niilistas, mas a autonomia de criação de novos valores fundamentados no pulsar próprio da vida. 
A fim de restituir ao homem esse potencial criativo e de transformação, Kazantzákis interioriza o niilismo nietzschiano, particularizando o escopo de sua atuação, transformando a afirmação dionisíaca do crescimento em meio ao declínio em uma aceitação total da vida. Com isso, propõe, segundo José Paulo Paes, um "niilismo heroico" (1985, p. 160) que leva as personagens kazantzakianas ao enfrentamento do perigo. O niilismo heroico é, pois, a recusa dos valores arraigados na tradição metafísica (individualidade, subjetividade, racionalidade, divindade salvadora, recompensa ao final da luta), contemporânea da aceitação heroica, dionisíaca, de participar da vida em sua plenitude, nas suas alegrias e nas duas dores.

Pelo niilismo heroico compreende-se a ânsia de Odisseu em manter-se em marcha, não permitindo que seu espírito se encerre nos estreitos limites fundadores de Ítaca, mas rompendo inicialmente com a família e a pátria para galgar novos degraus de sua elevação rumo à liberdade, que coincide plenamente com o poder criador do homem.

\section{A Marcha}

Se o Odisseu kazantzakiano é sustentado por uma nova visão de heroísmo niilista e dionisíaca - que vai além da constituição clássica, ainda que recupere seus traços, é natural que se investigue como se configura essa nova heroicidade, ciente de que certamente ela se estabeleça pela união com especificidades de outra figura: a do asceta.

Em Ascese, ao alcançar a etapa da Marcha, o herói se depara com o difícil percurso de superar a si mesmo, a raça, a humanidade e a terra, processo de elevação necessário para a libertação do asceta. No canto XIV da Odisseia, Ulisses afasta-se de seus companheiros para, sozinho, subir uma montanha às margens do rio Nilo, com o intuito de falar a seu coração, prometendo o retorno para quando seu espírito estiver maduro, ou seja, quando tiver alcançado a Visão de Deus para a construção da Cidade.

Percebe-se claramente uma inter-relação entre Ascese e o canto referido da Odisseia. Obra também disposta em etapas, a epopeia de Kazantzákis relata o percurso empreendido por Ulisses, desde sua chegada à Ítaca, levando-o a seguir os 
estágios estético, ético, metafísico e de plena liberdade até encontrar a morte, como libertação suprema de todas as ilusões mundanas. Ao se isolar no cimo da montanha, Odisseu inicia a etapa metafísica, na qual vive em seu espírito toda A Marcha ascética.

No primeiro degrau, que corresponde ao "Eu" em Ascese, Odisseu clama ao deserto de modo bastante semelhante ao herói da primeira obra na abertura do capítulo:

"No soy puro, no soy fuerte, no amo, tengo miedo!

Estoy lleno de barro y de vergüenza, estoy luchando en vano con plumas multicolores, con aullidos, con engaños y con viajes, para sellar los labios trémulos que en mi interior gritan "socorro!" Una capa barata de voces y lamentos y risas y sarcasmos, una máscara falsa y maligna y la llaman Odiseo.

¡Ah, qué vergüenza sobre tales cimientos construir mi ciudadela!’3

(KAZANTZAKIS, 1975, XIV, V.249-255)

O momento inicial da marcha apresenta a interiorização do herói, em reconhecimento (como a anagnórisis) de si mesmo, travando uma luta entre as trevas e a luz. Na solidão da montanha, Odisseu retira a máscara e revela que a aura de herói que o envolve não se coaduna com o grito angustiado e necessitado que aflora dentro de si. Esse autoquestionamento reflete a prática moderna da individualização, estando os sujeitos particularizados em relação à coletividade.

Não é possível, segundo Lukács (2007), encontrar na idade da epopeia (Grécia Clássica), ou mundo homogêneo, a separação entre mundo exterior e mundo interior, pois o homem épico não se afasta da exterioridade e se reconhece incorporado ao equilíbrio das forças sociais (família, pátria, amor). O herói da epopeia, ao contrário do indivíduo isolado, age em conformidade com o destino coletivo e com a vontade dos deuses. O mundo heterogêneo (mundo moderno), entretanto, é abandonado por Deus, o que tornaria os homens impotentes, não fosse a presença de uma "mística negativa", próxima do demoníaco. Com a perda da homogeneidade e com a ausência do divino, o homem conquista a reflexão e a liberdade, descobrindo em si o poder criador e a individualidade como potências para a superação das dualidades. O heroísmo moderno 
advém, portanto, da própria sobrevivência numa constante situação de conflito, pois sem a proteção dos deuses, o homem vive o percurso de sua vida em sua assustadora liberdade e perigo, em uma angustiante solidão e abandono. Assim sendo, a busca do homem moderno pela totalidade perdida marcaria uma espécie de presença do espírito épico na modernidade, enquanto a força necessária para sua sobrevivência configuraria uma outra modalidade da heroicidade.

Nota-se, portanto, que Odisseu participa da modernidade, sua constituição de herói baseia-se, em primeira instância, na ideia da entrega aos labirintos da subjetividade, não seguindo simplesmente os desígnios dos deuses e os costumes clássicos.

Porém, como o personagem está em marcha, a característica da individualidade não é seu último degrau. A superação do ego4 é necessária para que o herói compreenda que não luta sozinho, ao contrário está contido na realidade da interdependência budista, pela qual todos os seres, orgânicos ou inorgânicos, são partes de um mesmo todo e colaboram para a existência mútua. Assim, em constante superação de si mesmo, de dogmas e valores, Odisseu opera o descentramento de seu eu para o encontro do não-eu, estágio em que toma consciência de que, com ele, caminha sua raça.

Os antepassados, habitantes do Hades, reaparecem como fantasmas e rodeiam o herói. É o aviso de que não luta por si mesmo, mas deve saber que em suas entranhas correm o sangue e os feitos dos antepassados. Assim, Tântalo, Hércules e Prometeu, seus padrinhos, assomam à frente de Ulisses, para reavivar a necessidade de dar continuidade ao que iniciaram em vida e para recomendar-lhe a nova tarefa.

Com a aparição dos três "gigantes" míticos, representando as raízes de Ulisses, é decorrente a semelhança encontrada entre o herói e seus padrinhos. Se Tântalo é símbolo da fome e da sede eternas, Odisseu é o perpétuo insaciável de conhecimento, experiência e superação, sempre distanciado do que está ao seu alcance.

Do grande Héracles vem a força, a coragem e o gosto pela liberdade, bem como a cólera e a loucura, fraquezas que simbolizam a condição do ser humano às voltas com seu destino. Assim como Odisseu, Héracles passa por aventuras inúmeras, de elevado 
grau de dificuldade, que podem significar, segundo o pensamento místico, "as provações da alma que se liberta progressivamente da servidão do corpo e das suas paixões até a apoteose final" (GRIMAL, 2005, p.208). Cada um dos doze trabalhos se assemelha às diversas etapas de elevação de Odisseu, que, igualmente vestindo a cabeleira de leão (invisível aos olhos comuns) como elmo, atravessa terra e mar, enfrentando tormentas e sofrimentos. Como resultado desses périplos, que se iniciam já em Homero, Odisseu alcança e ultrapassa as Colunas de Hércules, fixadas por este no estreito de Gibraltar como limite para o percurso do homem. Navegar para além de Gibraltar significa transpor o limite em direção às trevas, o que de fato ocorre com o Odisseu de Homero ao transgredir o imposto para descer ao Hades.

A hybris, no entanto, já havia sido praticada por Prometeu, o terceiro antepassado. Grande benfeitor da humanidade, Prometeu liga-se a Odisseu pelas qualidades humanas, lembrando que na proposição da Odisseia clássica o termo andra anuncia que o motivo central de todo o poema está nos feitos do homem. Como herói, Odisseu não é um deus, mas um homem, e essa condição faz dele o representante da humanidade que enfrenta adversidades e sofre.

Mas a herança de Prometeu se estende. Ao ensinar os homens como obter o fogo, oferece-lhes o poder de manipular a natureza e, conseqüentemente, a libertação de Deus (Zeus). Por assim fazer, os homens já não mais precisariam da mediação divina, pois passavam a ser detentores do conhecimento reservado aos deuses; sem poderes sobrenaturais, o conhecimento (artifício humano) elevaria a casta humana ao patamar divino e a tornaria também criadora.

Desse modo Odisseu reencontra seus antepassados e redescobre em suas entranhas suas próprias potencialidades, como o herói insaciável, bravo e humano. Tampouco é o momento de parar, Odisseu deve se elevar ao degrau da humanidade:

Hablaba el viejo-combatiente y deshacía el mundo; Se movían y agitaban las fronteras, la especie humana entera Se alzó en el ser del arquero, y todos los ancestros mudos Se apartaron con terror para que entren todas las estirpes. Cuan pequeñuela su patria, y qué insignificante el suelo 
Que brotó de la mente y del sexo de su raza impotente.

Brotan en su interior estirpes de hombres, legiones se movieran,

Se extendió el alma por doquier, se hundió y echa raíces bajas:

Ni yo soy yo, ni son los ancestros que avanzan en mi ser;

Percibo en mí manos blancas y amarillas y negras,

Que sobre el abismo se agitan y me gritan: “iAuxilio!”

(KAZANTZAKIS, 1975, XIV, v. 629-639, grifo nosso)

Alargando seu círculo ao incorporar a humanidade, Odisseu vence definitivamente a etapa do individualismo, já não é tão-somente o eu e a raça que lhe formou, mas um corpo maior, aquele que abarca os homens todos. Tal constatação aproxima-se das ideias religiosas de irmanação cristã e interdependência budista.

O desapego da individualidade para o sentimento de participação no conjunto de homens reflete o despertar da consciência de que a humanidade caminha reunida e, portanto, a luta de um único homem se propaga pela multidão de homens. Assim, combatendo pela salvação de si mesmo e de toda a raça humana, brancos, amarelos e negros, Odisseu estará atuando pela salvação geral, o que reforça sua filiação a Prometeu. Tal interdependência implica, ainda, compromisso e responsabilidade; consciente de que sua ação repercute nas diversas pessoas e de que a salvação geral depende também da sua, Odisseu tem o dever de superar-se e de se entregar à luta heroicamente. Pois a heroicidade está em afastar-se de sua própria solidão para desafiar e ultrapassar os obstáculos que atingem e infelicitam os outros homens, em afastamento de seus próprios sentimentos para a cumplicidade com os conflitos do mundo.

E mais uma vez, sua alma se expande e abrange toda a Terra. Animais, vegetais, humanidade, terra e água gritam em Odisseu, necessitados de que a eles todos resgate:

Ya no era una voz solamente la que rompía las entrañas, no era ya solamente su estirpe ávida y de piel rugosa, ni ya sólo voces de hombres que brotaban dentro de él, mugidos, ladridos, aullidos, trinos y murmullos, brincaban como las aguas en lo profundo de sus riñones, y toda la tierra se agitaba, llena de alas y cuernos, en su sangre. 
(KAZANTZAKIS, 1975, XIV, v.690-695)

O círculo se fecha, Odisseu já está pronto para a visão do terrível segredo, aquele que revelará a verdadeira face de Deus.

\section{A Visão}

O processo de elevação culmina na iluminação ou despertar búdico, ou ainda, na epifania religiosa, por meio da qual Odisseu apreende o significado misterioso da face de Deus, suscitando a religação, o vínculo com o sagrado. Alguém grita em suas entranhas, e ele distingue não ser a voz de sua alma, dos antepassados, da humanidade ou da terra. Como um "centauro selvagem", Deus se revela a Odisseu:

"Mi cuerpo oscuro asciendo, mi hijo, por no ahogarme.

Me ahogan los árboles y los animales, me sofoco en mi cuerpo, $Y$ ya no quepo en tu alma y lucho por huir. ¡Ayúdame, hijo, a liberarme de tu carne lodosa y del alma estrecha y muda del humano!

¡Temo no conseguirlo, y perderme en la tierra también yo contigo!”

(KAZANTZAKIS, 1975, XIV, v.1041-1046)

A manifestação de Deus como um ser frágil, desesperado e clamando a ajuda de um homem desborda "a morte de Deus" insinuada por Nietzsche como necessária para a consolidação do super-homem. Kazantzákis realiza a inversão de atributos, oferecendo ao homem a força característica da onipotência divina, sem, contudo, eliminar a existência de Deus no cenário humano.

Estendendo a concepção da inversão para a doutrina budista, Deus desceria do Absoluto para a esfera do relativo, espaço onde a realidade é marcada pelo seu oposto e se estabelece por fenômenos. (GONÇALVES, s/d, p.14) Criador de ilusões no mundo terreno, o próprio homem seria a divindade esquecida, e teria como missão despertar o Deus oculto e sobrepujar a fantasmagoria. Mas um deus humanizado estaria despojado 
de seus poderes, agindo sensorialmente no mundo físico e dependente do homem para retomar suas faculdades absolutas e reais.

Para recuperar sua identidade original, ou verdadeira, o homem deve passar por um processo evolutivo de distanciamento do ego, filho da ignorância primordial, em direção a seu eu superior, idêntico ao Absoluto, ao Universal, ao Impessoal. Tendo já superado as etapas que o prendiam ao (ego)ísmo, Odisseu está mais próximo de sua natureza inicial; transubstanciando o ego em irmanação, irrompe o Deus em si, ainda que o herói não o reconheça imanente.

Ao contrário, a visão que retém da imagem divina nesta etapa da ascese é externa, como indivíduo igualmente lutando pela salvação. O que Odisseu vislumbra não é o deus terrível e inimigo, máscara ancestral, mas um velho mendigo pálido e de olhos encovados que tropeça nas pedras em sua ascensão, uma caminhada árdua e interminável. Evidencia-se, pois, o contraste marcante entre o velho debilitado e esgotado e o herói vigoroso e intrépido. A responsabilidade da salvação transfere-se para o homem, potencialmente mais capaz e que já não pode desfrutar de sua liberdade adquirida com a morte de Deus; compreende-se que tal Deus não está morto, mas rasteja entre as criaturas para não se perder.

A visão de um deus sofredor e inferior ao homem denota ainda que Odisseu alcançou a capacidade de "ver" o que é misterioso e oculto para as demais pessoas, como um profeta ou haríolo. Para as religiões da transcendência, os mistérios são inquestionáveis e considerados dogmas da fé, tornando-se inacessíveis ao entendimento dos fiéis. Apenas alguns "eleitos” recebem a dádiva de apreensão dos significados impenetráveis, ou segundo uma explicação mais racional, apenas alguns se reservam o direito de considerarem-se os eleitos e, portanto, esclarecedores das questões religiosas mais obscuras. Ligado a tais sentidos religiosos de "visão", Odisseu estaria próximo de Deus e de seu terrível segredo, tão perseguido por crentes, teólogos e filósofos.

Qual seria então o segredo, o significado ignoto do velho andrajoso e necessitado da caridade alheia? Para compreender essa manifestação divina delineada por Kazantzákis, é preciso refletir sobre as construções criadas para tal figura e a atuação da religião. 
Para a religião cristã, Deus é o ente que existe por si só, sem a dependência de qualquer outra entidade que o faça existir. Desse modo, Deus é causa necessária e o fim último de tudo, eterno e separado do mundo natural e humano. Já nas religiões primitivas, Deus é a designação dada às forças ocultas e nas politeístas aquele que influencia nos destinos do universo. Se nessas crenças, Deus está distanciado dos homens, as religiões da imanência, como o panteísmo, aproximam-no do mundo natural e até mesmo atribuem a ele características humanas. No entanto, em sentido contrário está a crítica filosófica de que a religião fomenta a alienação, exatamente porque os homens se esquecem de que são os próprios criadores da divindade soberana e onipotente, como se ela própria fosse a instauradora da realidade e os homens suas criaturas.

O pensamento de Bergson seria o elo mais fortemente entrelaçado com o Deus de Kazantzákis. Deus não está definitivamente morto, mas pode ser entrevisto como idêntico à vida e seus impulsos, considerando a existência independente da função fabuladora humana, o que não entra em desacordo totalmente com o pensamento de Nietzsche, já que, para o filósofo, a pulsação natural da vida deve ser respeitada. Pelas palavras de Will Durant fica clara a concepção bergsoniana sobre a força maior, a qual convencionou-se a denominação Deus:

Essa vida persistentemente criativa, da qual cada indivíduo e cada espécie é um experimento, é o que entendemos por Deus; Deus e vida são a mesma coisa. Mas este Deus é finito, não onipotente - limitado pela matéria e limitando a inércia desta matéria dolorosamente, passo a passo; e não onisciente, mas seguindo gradativamente, às palpadelas, em direção ao conhecimento, à consciência e a "mais luz". Deus, assim definido, nada tem de pronto para usar; Ele é vida, ação e liberdade incessantes. (DURANT, 1996, p. 422).

Assim, Deus não é onipotência, tampouco onisciência, mas completamente idêntico à incerteza da vida, caminhando por meio de tentativas conforme todos os seres existentes. Sem o poder e o conhecimento absolutos, Deus está igualmente limitado à estagnação da matéria, pela qual o élan vital atua na criação e manutenção da vida, sendo, portanto, uma escalada dolorosa. A representação desse Deus como um mendigo andrajoso5 é condizente com o esforço árduo e denso de se opor à matéria para o alcance da "mais luz", assim como sofrem todos os homens, os animais e as plantas em 
sua evolução. O inesperado da vida atinge também a Deus e é a sua luta, em conjunto com a de todos os seres, que proporciona a interminável criação. Não há aporia, portanto, entre a visão de um deus clamando por ajuda e a tradição de sua onipotência e soberania.

Iluminado por essa visão, Odisseu deve continuar o processo da ascese, que leva em seguida à ação. A suprema tarefa do homem está em colaborar na ascensão de Deus, pois a interdependência inerente a todos os seres revela que a salvação não poderá se efetivar individualmente senão pelo alcance coletivo.

No sólo liberas al dios, combatiendo, venciendo, sometiendo al caos sublevado a sólidas leyes, sino que engendras dios, arrastrándote en el suelo como una luciérnaga ¿Por qué combatiste tanto tiempo y jugaste dentro de tu espíritu, y todo te parecía fantasmas, artificios de la imaginación, alas de la cabeza embriagada, papagayos del logos que atravesaban el cerebro humano, chillando roncamente? Para que ya te liberes de la alegría del juego, Odiseo, y te apliques como obrero y jornalero a la tarea, y caves tú también, agachado, la viña del Dios, pues no queremos nosotros, sabes, vagabundos perezosos en la tierra, sino que queremos cavadores que al suelo como espíritus puedan aliviar.

(KAZANTZAKIS, 1975, XIV, v. 1364-1375)

Assim, Odisseu compreende que deve construir uma cidade para abrigar e proteger ao deus.

\section{A Prática}

Canta-me, ó Musa, o homem fértil em expedientes, que muito sofre Que destruiu a cidadela sagrada de Tróia Que viu as cidades de muitos homens e conheceu o seu espírito, Que padeceu, sobre as ondas, muitas dores no seu coração.

(HOMERO, 2009, I, V. 1-4) 
A invocação à Musa em Homero desnuda o espírito de Odisseu que ressoará na Odisseiade Kazantzákis: não só a engenhosidade múltipla revela seu caráter, mas o expansionismo, que o leva a estranhas terras e o torna fundador mítico de múltiplas cidades, como por exemplo a cidade de Lisboa, chamada de Olisipone ou Ulixibona, uma derivação do nome do herói. Constrói muralhas em Lisboa e um templo a Atena, em gratidão à sua proteção nos feitos de Tróia e no retorno à pátria.

Se, porém, Odisseu é conhecido como construtor, o oposto é igualmente verdadeiro, como canta o poema de Homero. Odisseu edifica muralhas em terras estrangeiras, mas destrói as de Tróia por sua astúcia. Em Kazantzákis a oposição entre o aniquilar uma cidade e o criar outra se mantém: Odisseu ateia fogo ao palácio de Knossos em Creta e levanta uma cidade para Deus em terras africanas.

De volta ao convívio entre os companheiros, Odisseu comanda a construção da cidade ideal, que abrigará a nova imagem de Deus e inaugurará um novo mundo. As muralhas se erguem, quatro portas em direção aos ventos, uma alta torre central e casas ao redor. Para Deus, uma ampla tenda. O homem da marcha incessante decide parar e encerrar-se na cidadela.

Clara é a associação da cidade de Odisseu com a Utopia de Thomas Morus, a cidade do Sol de Tommaso Campanella, a cidade de Platão contida na República, ou até mesmo a cidade de Deus de Santo Agostinho. Todas essas representações de um mundo idílico seriam uma esperança de organização do caos, de unificação da idealidade fragmentada nas cidades comuns. Ao mesmo tempo, a ânsia de recuperar o Éden perdido, ou instalar o Paraíso celeste na Terra repleta de vícios e sofrimento, bem como um modo de viver divinamente estando o Olimpo também no plano dos homens.

A busca da totalidade perdida retoma a discussão sobre os mundos homogêneo e heterogêneo, ou seja, na época clássica, os homens não eram distintos do espaço e não estavam representados por uma subjetividade, separados dos outros homens, mas caracterizavam-se por uma unicidade e totalidade, que foram perdidas com o florescer do mundo moderno. 
Mas a correspondência avança para a Atlântida mítica descrita primeiramente por Platão em Timeu e Crítias (1981). Cidade perdida, cuja existência nunca foi comprovada, a Atlântida chegou ao conhecimento de Platão, indiretamente, por Sólon, que estivera no Egito, onde ouvira a história de uma cidade mais antiga que Atenas e mais avançada em civilização, fundada por Poseidon. Próspera e ideal em moralidade, conhecimento e harmonia, Atlântida localizava-se para além das colunas de Hércules, onde nenhum grego havia chegado até Ulisses. Porém, relata o mito, quando a cidade começou a se corromper, um gigantesco tremor de terra levou-a à destruição no espaço de um dia e uma noite, desaparecendo no mar.

Pode-se ainda levantar a hipótese de que a Atlântida seja a própria civilização minoana, existente entre 2500 e 1200 a.C. Localizada na atual Santorini, próxima à ilha de Creta, tal civilização é considerada também avançada e foi dizimada por um vulcão, restando apenas vestígios arqueológicos. A cidade de Kazantzákis igualmente se erige para além das colunas de Hércules, assim como Atlântida, e sucumbe por um terrível vulcão no dia de sua inauguração, o que nos leva a ponderar a possibilidade de que Kazantzákis, como cretense e grego, tinha conhecimento desses relatos. 6

Ao lado de Sikelianos, um dos projetos de Kazantzákis na juventude era a construção de uma comunidade ideal, na qual todos viveriam para a arte e para o bom relacionamento humano. $\mathrm{O}$ autor não concretiza sua utopia, mas Sikelianos procurou, na prática, converter Delfos, lugar sagrado do helenismo, em um centro de confraternização intelectual e espiritual de homens de todas as nações, chegando de fato a promover no local festivais ao ar livre, com representações de Ésquilo, espetáculos de dança e competições atléticas.

Considerado na época clássica o umbigo do mundo, Delfos era um lugar sagrado e visitado por inúmeros peregrinos em busca de revelações do oráculo. A crença de que o centro representa um ponto ideal, relativo ao espaço sagrado e não ao profano tem raízes nas primitivas religiões e, talvez, permaneça no imaginário do homem atual. (ELIADE, 1991) Circular, a cidade de Odisseu pertenceria também à ideia da sacralização, locus de união entre o homem e Deus, uma forma de concretizar o ideal de Santo Agostinho no patamar terreno. 
Diante da fogueira, antes de dar início à elevação da cidade, Odisseu traça um círculo de cinzas na terra para dar visualidade aos companheiros de seu projeto, do mesmo modo que Alexandre, o Grande, na ocasião da construção de Alexandria7. Aqui nos aproximamos de mais uma associação: Alexandria é uma cidade do Egito às margens do rio, onde aflora também o deserto, magnífica em cultura, prosperidade e beleza.

O fundador de Alexandria liga-se intimamente a Odisseu por outros aspectos igualmente. Grande figura do heroísmo helênico, Alexandre descende da linhagem de Hércules, representando igualmente a insaciabilidade. Suas conquistas de territórios e impérios refletem a insatisfação que o acometia quando alcançava novas fronteiras; enquanto o ideal de conquista da próxima terra permanecia, ele não cessava, avançava, uma vez conquistada, toda a ilusão se desvanecia, imagem que o aproxima igualmente de Tântalo. Alexandre foi incompreendido pelos companheiros de batalha por sua ânsia de manter-se constantemente em marcha, quando já não era mais necessário, tamanhas eram suas conquistas, mas fixar-se em um território, contentar-se com o conhecido, representava a estagnação e o modo de aprisionamento a valores.

Mas Odisseu, detentor do segredo de Deus, acreditou ser possível encerrar o percurso; se Ítaca não representou a satisfação plena, a Cidade Ideal poria fim às suas andanças, assim como o Eneias errante em busca de construir uma cidade para repouso final de seu povo.

Para estabelecer os alicerces da cidade, Odisseu promove festas de fertilidade, impelindo o povo à frutificação dentro dos limites do círculo sagrado, do mesmo modo que cultua a mãe-terra, já que tais ritos se associam à deusa Deméter, bem como a Dioniso, o criador-destruidor, o amante ébrio. $8 \mathrm{Se}$ os descendentes são a grande sustentação da cidade, os velhos têm como destino a queda no abismo, pois são vistos pelo herói como impulso vital que já não cria ou produz frutos.

Como Moisés, para fortificar e imortalizar sua cidade, Odisseu grava um novo decálogo em dez negros rochedos: 
"Gime Dios, hace palpitar mi corazón y me grita:¡Auxilio!"

"iSalta Dios desde las tumbas, no lo contiene la tierra!"

"iSe sofoca Dios en los vivientes, con ira las patea y se marcha!"

"iTodos los vivientes, a siniestra y a la diestra, son sus fieles apoyos!"

"¡Ama ya al pobre ser humano, pues lo eres tú, hijo mío!"

"Ama ya a los animales y las plantas, pues eso era tú, y ahora

en la enconada batalla te siguen como fieles servidores y compañeros."

"Ama toda la tierra, agua y polvo y piedras;

sobre ellos me sostengo para no caer, y no tengo otro corcel."

"¡Niégate las alegrías, las riquezas, las victorias cada día!"

"No es la virtud más grande de la tierra el llegar a ser libre,

sino vigilante e implacable e indestructiblemente querer la libertad."

Y coge la última oca y graba una esbelta saeta

con un pico sediento, que se lanza a lo alto, hacia el sol.

(KAZANTZAKIS, 1975, XV, v. 1161-1174)

A tentativa de assentar Deus na Terra, de armazenar sua essência nas muralhas humanas, e por meio dela proporcionar a salvação do mundo a todos - homens, animais, vegetais, águas e pedras - é mal sucedida. A moralidade, os bons princípios e a nobreza de caráter são determinantes para a permanência das cidades ideais erigidas pela humanidade no decurso do tempo; cidades corrompidas pela cobiça, pela luxúria e pelos desvios de conduta e de leis terminam arruinadas por algum fenômeno da natureza, como resposta à incompatibilidade entre o "mundo das ideias" e o "mundo sensível", ou ainda a punição pela hybris cometida.

No entanto, não é exatamente o que ocorre com a cidade de Odisseu; desta vez, o destruidor de Troia e de Knossos vê sua idealização arrebatada, as ideias da estagnação, do repouso e da imortalidade forjada nas pedras contrariam a natureza e o impulso vital. Não é o Deus todo-poderoso que desperta o vulcão para abrasar a cidade, mas o próprio ritmo das forças naturais. Deus não pode conter-se na matéria, precisa evadir, saltar, ir em direção ao "sempre mais". A marcha ininterrupta do homem (Odisseu) é a mesma de Deus, e as muralhas fortificadas, as pedras dos novos dez mandamentos são uma incongruência com a necessidade de movimento, ação e liberdade para o alcance da salvação.

Sobre as ruínas da cidade dizimada e sobre os corpos de seus últimos companheiros de marcha, Odisseu compreende que recebera da mãe-terra a lição mais 
inclemente: a necessidade de sobrepujar também a esperança. Mais além da tristeza, da felicidade ou amor, sem ilusões, sem Deus. Desse modo, alcança a plena liberdade, interstício de comunhão com a pátria completa - o exílio eterno - e com a verdadeira fortaleza - corpo e alma. Com o espírito liberto de fabulações e de frutos a alcançar nessa marcha incessante, Odisseu chega à "santidade", elevado ao patamar da nãocrença e da não-esperança.

\section{O Silêncio}

Nesta etapa da elevação, em que o silêncio reina e poderíamos incorrer em dissonância, já que as palavras destoam do estado de ataraxia e não podem jamais explicar o que é tal iluminação9, resta-nos, não o silêncio acerca da obra, mas procurar traçar uma trajetória crítica do herói que empreendeu a ascese.

No Livro X da República, Platão apresenta o momento em que as almas de várias figuras célebres estão concentradas em escolher seu destino para a nova encarnação. Entre as figuras de renome está Odisseu, que escolhe o destino jazente em um canto, desprezado por todos: a vida comum. Odisseu renuncia à fama, à ambição, ao sofrimento e ao heroísmo, não deseja ser um mito, mas um indivíduo particular, privado. Como protótipo do antimito, o herói se transforma, após a morte, em um desconhecido, o ignoto viandante da profecia de Tirésias.

O Odisseu de Kazantzákis igualmente caminha rumo à perda do nome: deixa de ser o saudoso rei de Ítaca e o famoso marido de Penélope, ao abandonar a pátria; renuncia às recompensas por tantos anos de sofrimento, à beleza, representada por Helena, deixando-a em Creta após tê-la raptado, à Grécia, incendiando o palácio de Knossos para navegar em direção ao Egito.

A ancoragem de Odisseu no Egito, local visto como a terra dos mortos no pensamento clássico, representa, mais uma vez, o aniquilamento do eu para tornar-se o desconhecido, o estrangeiro. Até mesmo em Homero o herói aparece sem o nome, ocultando sua identidade sob o disfarce de mendigo, quando finalmente chega à ilha, um artifício para que não seja desconhecido pelos familiares, ou seja, a perda do nome 
protegeu-o e possibilitou o reconhecimento diante de Eumeu, Euricléia, Penélope e Laertes.

É necessário, portanto, a perda do nome para salvar o "dono" do nome, como se ele fosse um aprisionamento do ser. Podemos inferir, desse modo, que a linguagem é insuficiente para revelar através do nome o que está oculto sob ele; no apagamento do nome estaria, pois, a salvação.

A trajetória do Ulisses kazantzakiano reflete a busca pelo desvanecimento do renome e do nome. Mas a ascese não pode ser empreendida portando o nome, é apenas pela perda gradual do ego que o asceta atinge a liberdade, podendo, como parte interdependente, comungar com o todo e reconhecer sua natureza divina.

O niilismo heroico fundamenta essa perda do nome, que faz de Odisseu um desconhecido: sorver a vida até a borra10, conhecer tudo e tudo viver, para então renunciar ao já conquistado: o amor, o heroísmo, a liderança e a própria santidade. Odisseu persegue ideias, mitos, conjuga os "guarda-costas de seu espírito", preenche-se com eles até se saciar, dissolvendo e esgotando o todo em nada. Assim, podemos compreender Odisseu em sua natureza dupla (destruidor/construtor) pelas palavras do poeta português Fernando Pessoa em seu poema "Ulysses" (integrante de Mensagem): “O mytho é o nada que é tudo.” (1996, p.17).

\section{Referências}

BERGSON, H. A evolução criadora. São Paulo: Martins Fontes, 2005. As duas fontes da moral e da religião. Rio de Janeiro: J. Zahar, 1978.

BOITANI, P. A sombra de Ulisses. São Paulo: Perspectiva, 2005.

DURANT, W. A história da filosofia. Rio de Janeiro: Nova Cultural, 1996.

ELIADE, M. Imagens e símbolos. Ensaio sobre o simbolismo mágico-religioso. São Paulo: Martins Fontes, 1991.

ELIOT, T. S. Poesia. Tradução: Ivan Junqueira. Rio de Janeiro: Nova Fronteira, 2006.

GONÇALVES, R. M. (Org.). Textos budistas e zen-budistas. São Paulo: Cultrix, s/d.

GRIMAL, P. Dicionário de mitologia grega e romana. Rio de Janeiro: Bertrand Brasil, 2005. 
HOMERO. Odisseia. Tradução: Carlos Alberto Nunes. Rio de Janeiro: Ediouro, 2009. KAZANTZAKIS, N. Odisea. Traducción de Miguel Castillo Didier. Barcelona: Planeta, 1975. 1997.

. Ascese. Os salvadores de Deus. Tradução José Paulo Paes. São Paulo: Ática,

LUKÁCS, G. A teoria do romance. São Paulo: Duas Cidades/ Editora 34, 2007.

NIETZSCHE, F. Assim falou Zaratustra. São Paulo: Martin Claret, 2000.

PAES, J. P. A última viagem de Ulisses. In: Gregos e baianos. São Paulo: Brasiliense, 1985.

PESSOA, F. Mensagem. ALLCA XX: Scipione Cultural, 1996.

PLATÃO. A República. São Paulo: Martin Claret, 2005.

Timeu e Crítias ou a Atlântida. São Paulo: Hemus, 1981.

PLUTARCO. Vidas paralelas. Alexandre \& César. Porto Alegre: L\&PM, 2005.

STANFORD, W.B. The Ulysses theme. Ann Arbor, 1968.

TENNYSON, A. Ulisses. Tradução: Haroldo de Campos. In: BOITANI, P. A sombra de Ulisses. São Paulo: Perspectiva, 2005. p. 223-226.

1 Doutoranda em Letras (área de concentração: Teoria da Literatura), IBILCE, Universidade Estadual Paulista-UNESP, São José do Rio Preto-SP. Bolsista FAPESP. E-mail: biabeca@gmail.com

2 No poema Ulysses do autor inglês, o herói se impacienta em sua ilha e despreza sua raça; com o espírito sedento por conhecer a si mesmo e almejando novas experiências, toma novamente o largo com alguns companheiros.

3 Para confrontação das palavras de Odisseu com as do herói em Ascese: "Não sou bom, não sou puro, não sou tranqüilo! É insuportável a minha ventura e a minha desventura também; estou cheio de vozes inarticuladas e de trevas; rolo em lágrimas e sangue na manjedoura da minha carne./ Tenho medo de falar. Enfeito-me de penas falsas, chamo, canto, choro para sufocar o grito impiedoso do meu coração." (KAZANTZAKIS, 1997, p. 65).

4 Interessante notar que a perda do ego, ou a sua superação, sempre esteve diretamente ligada às figuras religiosas, como o santo e o asceta. Como as diversas religiões pregam a compaixão, tais figuras se esmeram na subjugação de seus interesses pessoais e de uma individualidade, pois o eu leva ao egoísmo. Distanciados de si mesmos, santo e asceta podem cumprir a missão de auxílio aos homens de modo mais eficaz e, conseqüentemente, estão mais próximos de Deus. Em Kazantzákis, tal ascetismo ou santidade se confunde com a responsabilidade da escrita. 
5 A etimologia da palavra "andrajoso" é obscura e incerta, mas seria completamente absurdo relacioná-la à "andra" (no contexto, Deus vestido de homem)?

6 Obviamente não nos interessa as especulações sobre a existência ou não de Atlântida e a hipótese de sua semelhança com a civilização minoica, interessantes apenas a arqueólogos e historiadores. O que nos diz respeito é a correspondência que tais cidades evocam na obra de Kazantzákis, já que o autor pode ter se inspirado em tais tradições para a construção de sua própria cidade, como diálogo entre culturas e mitos, assunto concernente à literatura.

7 Segundo Plutarco (2005, p.50), Alexandre traça com farinha o projeto de Alexandria, também um círculo. Pássaros pousam sobre o traçado e comem toda a farinha. Alexandre fica perturbado com o presságio, mas os adivinhos lhe afirmam que era um sinal de que a cidade seria rica e farta. As cinzas de Odisseu não são levadas, mas é exatamente o que se torna a cidade tempos depois.

8 A fertilidade na cidade de Odisseu contrapõe-se à esterilidade em The waste land (1922) de T.S. Eliot, poema visionário que expressa o fracasso da vida moderna, da perda de sentido na existência dos homens do século XX, por meio de uma cidade arruinada. Deve-se associar Kazantzákis à percepção de Eliot, pois o poeta grego igualmente sentiu a atmosfera de decadência que marcou as primeiras décadas do século, como uma época de crise e de desequilíbrio, exigindo que todos combatessem a favor do impulso vital, o que pode ser constatado em Ascese e também na Odisseia.

9 O Nirvana búdico está exatamente na não-conceituação, pois o seu oposto é o entrave para "o despertar". Apenas a libertação de dogmas, religiões e filosofias propicia o caminhar para a iluminação.

10 Cf. poema Ulysses de Tennyson: "Não posso descansar da viagem: quero/ Beber a vida até a borra. Frui tudo..." 